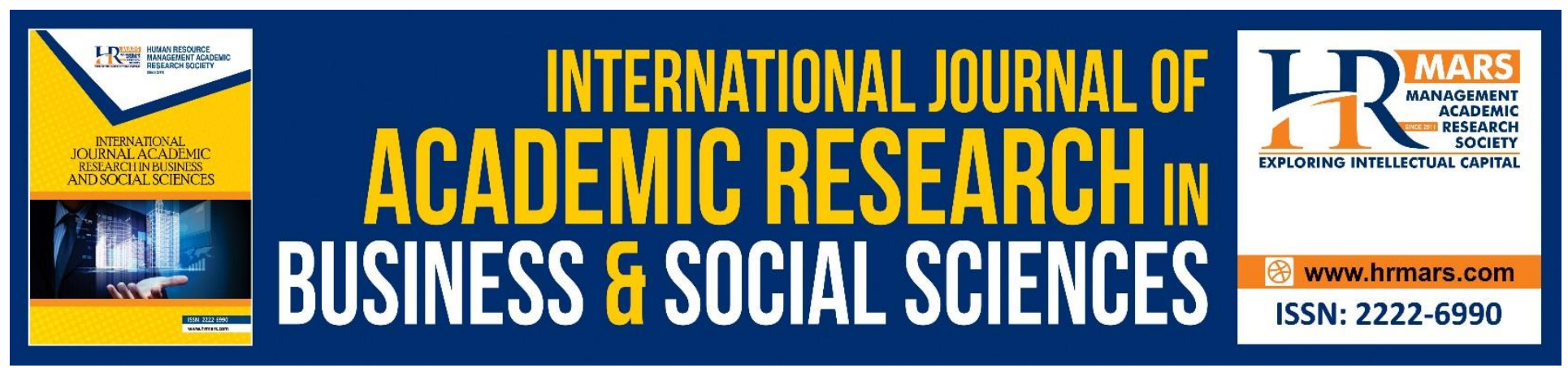

\title{
The Relationship between Human Resource Management Practices and Job Performance in the Courier Service Industry
}

Ong Choon Hee, Maria Angelina Halim, Lim Lee Ping, Tan Owee Kowang, Goh Chin Fei

To Link this Article: http://dx.doi.org/10.6007/IJARBSS/v9-i3/5630

DOI: $\quad 10.6007 /$ IJARBSS/v9-i3/5630

Received: 13 Feb 2019, Revised: 03 March 2019, Accepted: 30 March 2019

Published Online: 07 April 2019

In-Text Citation: (Hee, Halim, Ping, Kowang, \& Fei, 2019)

To Cite this Article: Hee, O. C., Halim, M. A., Ping, L. L., Kowang, T. O., \& Fei, G. C. (2019). The Relationship between Human Resource Management Practices and Job Performance in the Courier Service Industry. International Journal of Academic Research in Business and Social Sciences, 9(3), 63-79.

Copyright: (C) 2019 The Author(s)

Published by Human Resource Management Academic Research Society (www.hrmars.com)

This article is published under the Creative Commons Attribution (CC BY 4.0) license. Anyone may reproduce, distribute, translate and create derivative works of this article (for both commercial and non-commercial purposes), subject to full attribution to the original publication and authors. The full terms of this license may be seen at: http://creativecommons.org/licences/by/4.0/legalcode

\section{Vol. 9, No. 3, 2019, Pg. 63 - 79}

Full Terms \& Conditions of access and use can be found at http://hrmars.com/index.php/pages/detail/publication-ethics 


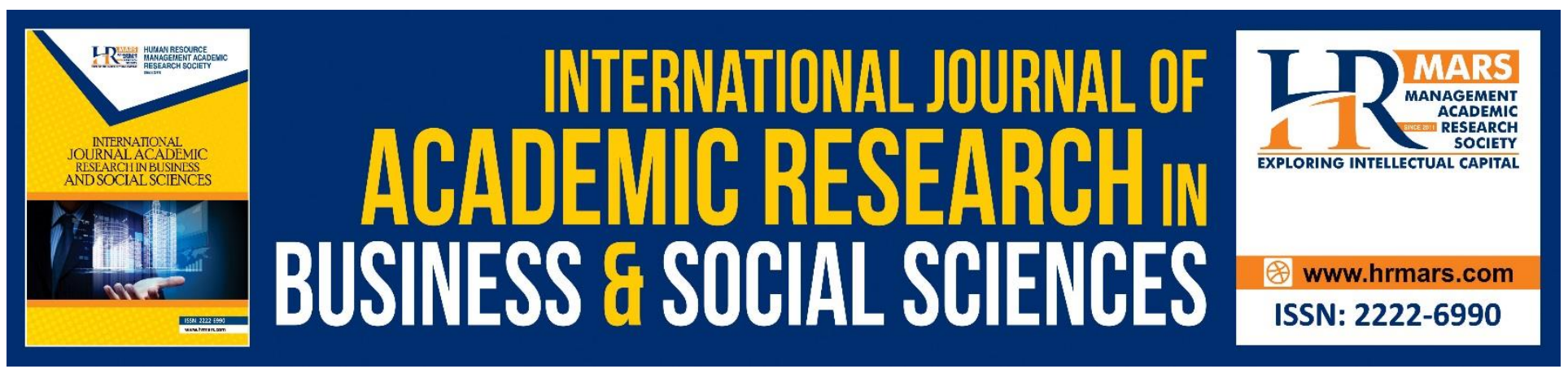

\title{
The Relationship between Human Resource Management Practices and Job Performance in the Courier Service Industry
}

\author{
Ong Choon Hee, Maria Angelina Halim, Lim Lee Ping, Tan Owee \\ Kowang, Goh Chin Fei \\ Azman Hashim International Business School, Universiti Teknologi Malaysia, Johor, Malaysia. \\ Corresponding Author: ongchoonhee@gmail.com
}

\begin{abstract}
The purpose of this study is to examine the relationship between Human Resource Management (HRM) practices and job performance in the courier service industry. Data was collected through questionnaire from 100 employees of a courier service company in Johor, Malaysia. The results of the multiple regression analysis showed that employment security and training and development were significantly related to job performance. The findings suggested that employment security is the most important factor that positively influences job performance followed by training and development. Compensation and benefits and performance management were found to be not significant in predicting job performance. In relation to these findings, human resource department shall put effort to create a climate of confidence on the company's work force so that employees will feel more secured and design suitable training programs that lead to the acquisition of new knowledge and skills for personal growth and enhancing job performance.
\end{abstract}

Keywords: Job Performance, Training and Development, Compensation and Benefits, Performance Management, Employment Security, Good and Safe Working Environment, Courier Service Industry.

\section{Introduction}

The advancement of technology has enabled goods delivery beyond borders and allowed massive improvement to the services offered by courier companies. In the current situation and dynamic business environment, companies tend to rely more on transportation for their business (Karthikeyan \& Elango, 2014). In one organization, it is crucial to know how its employees perform because employees represent the organization's image to the public. Amin, Ismail, Rasid, \& Selemani (2014) stated that employee are one of the most important assets of an organization as they contribute to its growth and success. According to Aboul-Ela (2017), organization itself was built by many individuals who respond, interact, and share lives together at one place. According to Borman and 
Motowidlo (1993), contextual performance consists of activities that are beyond the basis requirements of individual job position. They stated that job performance was considered contextual because employees perform his or her duties in the organization to the extent that support the organization in achieving its goals. Generally, job performance has been studied for long time (Caillier, 2010). For the past 10 years, there were increasing of researches attempt to clarify that human resource management practices could result in higher organizational performance (Wright, Gardner, Moynihan, \& Allen, 2005). A study of MacDuffie (1995) investigated about the relationship between human resource management practices and productivity in assembly plants. It was found that human resources practices were related to productivity. On the same note, Guthrie (2001) conducted a research on the relationship between human resources management practices, turnover and productivity. The findings showed that there is a significant relationship between the variables. According to Johari and Yahya (2016), job performance is one of the most important criteria in measuring industry performance in the organizational psychology research. By conducting research in the area of human resource management practices, it will assist the organization to improve its employee's work efficiency, productivity and effectiveness. Datta, Guthrie, and Wright (2005) reported that human resource management practices enhanced firm performance. This study specifically examined the influence of human resource management practices on job performance in the courier service industry. The findings of this study provide insights to courier service provider to understand the importance of human resource management practices on job performance. Therefore, this study intends to examine the variables empirically in the Malaysian context and it is expected that the research model could provide significance information to the courier service provider in relation to enhance job performance via human resource management practices.

\section{Literature Review \\ Job Performance}

Organization and its employees perceived performance as an important element in the business environment because performance impacts promotion, employee's turnover, and organizational market value (Caillier, 2010). Locke, Mento, and Katcher (1978) defined performance as an ability or motivation of a person. Job performance is one of main factors that relates to employees when they are working in an organization. Yang and Hwang (2014) stated that this factor measures employee's achievement against his or her goals, focuses on the outcome whether the outcome remains the same exceeds his or her expected goals. Kahn (1990) expressed in his research that after employees engaged with the organization where they work at, they will devote their emotional, intellectual, and physical aspects to their performance. According to Johari and Yahya (2016), job performance is one of the most important criteria to conduct measurement in an industry or in an organizational psychology research. Giri and Kumar (2009) concurred that job performance can be seen as a person's ability to perform their job excellently whereas Vratskikh, Masadeh, Al-Lozi, and Maqableh (2016) stated that job performance is associated with human resource practices because human resource personnel generally intend to enhance employees' performance via promoting good attitudes, giving incentives to the employees if they perform well, encouraging employees satisfied with their works and other rewards to increase employees' motivation. Likewise, Johari and Yahya (2016) stated that job performance was the significant indicator when conducting measurement of employee's 
performance even though job performance has been explained in many ways. Bhatti, Sundram, and Hee (2012) categorized job performance into two dimensions, namely task performance and contextual performance. Correspondingly, Aboul-Ela (2017) defined task performance as employee's ability to do their job based on job description while contextual performance was explained as voluntary action of an employee that is not related to their job description. Examples of contextual performance are more likely associated with exercising efforts, enhancing and encouraging team performance, having good cooperation and transparency in communication (Rotundo \& Sackett, 2002). Friedman, Tidd, Currall, and Tsai (2000) clarified in their research that when employees have broad knowledge and capabilities to take part and contribute their ideas to the organizations, this is the moment when their job performance will be enhanced because they provide better solution and develop suitable adaptability towards the current situation.

\section{Human Resource Management Practices}

There are several concepts of Human Resources Management that being defined by researchers. Researchers have identified and investigated human resources management practices which vitally developed organizational competitive benefits (Pfeffer \& Veiga, 1999). Schuler \& Jackson (1987) described human resources management as a group of management activities that aligned with organizational goals. It is a group that consists of practices that used for the organizations to manage its employees. Human resource management covers some practices that reflect the needs of current business, namely recruitment and selection, training and development, compensation and benefits, performance management and employment security. Organizations are likely to adopt at least one or two practices to apply in the workplace (Izvercian, Radu, Ivascu, \& Ardelean, 2014). Heraty and Morley (1998) believed that organization lucrativeness is depend on the quality and performance of the employees which are related to human resource practices. Similarly, Ong \& Koh (2018) described that human resource is more likely to emphasize on employee's skills more than other elements. Huselid (1995) argued that human resource management practices are likely to influence employee's behavior and motivation after the organization decided to adopt it and give the employees the opportunity to develop their capabilities. By acquiring suitable practices, employees would be able to establish new skills and behaviors. Thus, theories are suggesting that human resource management practices influence employee's skill and motivation through organizational structure and ultimately improve their job performance in the organization.

\section{Training and Development}

According to Aguinis (2013), training is about a systematic approach to learning and development to improve individual, team, and organizational effectiveness. On the other hand, development refers to activities leading to the acquisition of new knowledge or skills for the purposes of personal growth. Coetzer, Redmond, and Sharafizad (2012) explained that the purpose of training is to enable an individual to acquire abilities in order to perform adequately when given a task or job. Nadarajah, Kadiresan, Kumar, Nissa, \& Yusoff (2012) concurred that after employees become well trained, they can share their knowledge and skills with others to improve service and performance of the organization. By attending training and development programs, employees will be more committed and motivated to improve their overall capability and performance. Jyothi and Venkatesh (2012) 
added that training is a process of enhancing efficiency, capacity, effectiveness and job performance at work. The training functions include identifying training needs at the individual, group, and organizational levels, designing training programs and evaluating the effectiveness of training programs. Therefore, based on above discussion, it is hypothesized that:

H1: Training and development is positively related to job performance

\section{Compensation and Benefits}

Compensation and benefits are significantly important in most of the high performance work systems (Pfeffer \& Veiga, 1999). Hameed, Ramzan, Zubair, Ali, \& Arslan (2014) stated that in service industry, compensation and benefits are major factors for employees to exhibit good performance. According to Amin, Ismail, Rasid, and Selemani, (2014), compensation and benefits are reward systems that a company provides to individuals in turn for their willingness to perform various jobs and tasks within the organizations. Hameed, Ramzan, Zubair, Ali, \& Arslan (2014) further explained that compensation and benefits are outputs in a form of pay or rewards being given to increase employee performance. Vlachos (2009) identified that compensation and benefits are wider than wages or salaries, they are also include commissions, bonuses, allowances, and reimbursements. Additionally, Ong \& Koh (2018) found compensation and benefits in various forms such as monetary rewards, leaves, recognition package, and medical insurance. In a study of Vlachos (2009), it was highlighted that compensation and operational performance in an organization are related to each other. Compensation and benefits are able to increase personal job performance based on few studies by Jyothi and Venkatesh (2012) and Algorta \& Zeballos (2011). These researchers gave examples where bonuses were given to employees when they displayed good performance. Other examples of benefits were product discount, life or work insurance, free vehicle insurance, extra day for holidays, special gifts and excellent performance award. Sometimes, compensation also includes profit sharing, stock ownership, and team incentives. When employees feel that they are part of owning the organization, they will be more motivated to perform well (Pfeffer \& Veiga, 1999). Hence, based on the above explanation, it is hypothesized that:

H2: Compensation and benefits are positively related to job performance.

\section{Performance Management}

Performance management is a continuous process to maximize employee's productivity and performance in the organization. It includes incentives, objectives and values. Mondy (2012) explained that if an organization did not emphasize on performance management, most likely the organization will fail owing to wrong strategies. Fletcher (2001) defined performance management as a way to enhance performance of the employees and organizations and assist employees to contribute more towards their job. On the other hand, Armstrong and Baron (2004) described performance management as a means of getting better results from the entire organization by understanding and managing within an agreed framework, planned goals, standards and fulfilling competency requirements. They claimed that the focus of performance management is on elements such as recognition, constructive feedback, personal development and career opportunities. 
According to Sang, Korir, and Wishitemi (2016), a good human resource management will enhance performance management too. It is about how well human resource management is being managed and it will affect job performance of the employees later. The main purpose of the performance management process is still largely revolving around personal performance objectives setting and appraisal against the objectives. Thus, based on the above discussion, it is hypothesized that:

H3: Performance management is positively related to job performance.

\section{Employment Security}

Clarke \& Patrickson (2008) defined employment security as an ability of an employee to find, retain, and change between industries that have vacancies. Nadarajah et al (2012) added that employment security is a feeling that not concerning about losing a job. These researcher explained that when employees feel their jobs are remain secured, they will focus more on the task that was given to them instead of looking for job opportunities. In contrast, when employees do feel insecure, most likely they could not perform well. Numerous research have focused employment security as one of the fundamental elements in terms of imposing impact towards performance in an organization (Pfeffer \& Veiga, 1999). It is possible for organization to create innovation or improve its productivity when employees feel secured with their jobs. Employees will put effort and contribute more when they are being guaranteed a job in the organization. Pfeffer and Veiga (1999) continued to emphasize that organizations gain benefits via securing its employee from crossing over to its competitors. Organization must have trained and developed its work force in order for the employees to perform well. By laying off employee means that the organization is giving up valuable assets to the market which be collect by its competitors later. Nadarajah et al. (2012) clarified that if an organization does not lay off employees periodically, employees will feel more secured. Employment security maintains high performance among employees and creates a climate of confidence in the company's work force. Based on discussion above, it is hypothesized that:

H4: Employment security is positively related to job performance.

\section{Safe Working Environment}

A safe working environment provides protection to an individual from any near miss, dangerous occurrence and accidents. When employees encounter harmful events or unsafe working environment, it will affect their performance in the organization (Mondy, 2012). Caillier (2010) explained that work environment refers to numerous factors that are related to the administrative setting in which employees are working at. According to Caillier (2010), factor such as work environment may have been used by researchers to describe employees' behaviors and their job performance. Carlopio and Gardner (1992) highlighted in their study that employees will get affected by the work environment in the organization. Every employee has to work in an environment that direct or indirectly affects their talents and aspirations. Knudsen, Busck, \& Lind (2011) reported that since 1970, work environment has been linked to work-related health and safety in Scandinavian countries. Nowadays, it further links to other factors that could influence both physical and social environment in terms of quality of work life. This practice is important because employees that work 
in a safe environment and able to maintain good health are more likely to be more productive and yield long term benefits to the organization (Mondy, 2012). Bakker, Tims, \& Derks (2012) clarified that numerous study proposed results that employee will work best in a challenging, resourceful and safe work environment. It means organization should provide social and physical support to the employees and in return, employee will feel encouraged to work well. Additionally, Algorta and Zeballos (2011) stated in their study that if a company is willing to pay attention on safe work environment, it will definitely help employee to perform better in a conducive and accident-free environment. Therefore, based on the explanation above, it is hypothesized that:

H5: Safe working environment is positively related to job performance.

\section{Methodology \\ Population and Sample}

The target population was obtained from few companies in the courier service industry in Johor, Malaysia. The unit of analysis is the individual employee that works in the courier service companies that located in Johor Bahru. To get better and valid results, the size of sampling was referred to the sampling table of Krejcie and Morgan (1970) for determining sample size needed (S) given the number of population (N). The population for this study is 120 . In accordance with the sampling table, the required sampling size is 92 .

\section{Method and Instruments}

This study employed quantitative method. The samples were generated through simple random sampling technique. Questionnaires were distributed in two ways via online electronic questionnaire and administered on site via printed media. The job performance scale (10 items) was adapted from Farh, Earley, \& Lin (1997), J. William \& Anderson (1991), and Borman \& Motowidlo (1993). For training and development (6 items), measures by Delaney \& Huselid (1996), J. William \& Anderson (1991), Egdar \& Geare (2005), and Hartog, Boon, Verburg, \& Croon (2013) were used in the study. Meanwhile, compensation and benefits ( 5 items) were measured by instruments adapted from Delaney \& Huselid (1996) and Heneman \& Schwab (1985). Five items of measurement developed by Chang (2005) \& Rogg et al. (2001), J. William \& Anderson (1991), and Hartog, Boon, Verburg, \& Croon (2013) were employed to measure performance management. Measures for employment security were adapted from J. William \& Anderson (1991), Chang (2005), and Hartog, Boon, Verburg, \& Croon (2013). Finally, measures for safe working environment were adapted from J. William \& Anderson (1991) and Egdar \& Geare (2005). Likert scale was used to measure the level of agreement for job performance and the respective human resource management (HRM) practices. The measurement scale was anchored by 1 (Strongly Disagree), 2 (Disagree), 3 (Neither Agree nor Disagree), 4 (Agree) and 5 (Strongly Agree).

\section{Data Analysis}

In this study, validity test and reliability were performed to evaluate construct validity and internal consistency for all the study variables. Methods employed for inferential analysis were correlation 
INTERNATIONAL JOURNAL OF ACADEMIC RESEARCH IN BUSINESS AND SOCIAL SCIENCES

Vol. 9, No. 3, March, 2019, E-ISSN: 222 2-6990 ¿ 2019 HRMARS

analysis and multiple regression analysis. Statistical Package for Social Sciences (SPSS) software was used to analyse the data collected.

\section{Results}

\section{Profile of the Respondents}

The researcher distributed 120 questionnaires to every level of the employees that work in the courier service companies. From the 120 questionnaires, only 100 questionnaires were collected and deemed usable in this study. The researcher investigated the profile of the respondents via gender, age, years of working experience, position in the organization, and their academic qualification. There was a greater percentage of male respondent $(60,60 \%)$ compared to female $(40,40 \%)$. Majority of the respondents were having 1-2 years of experience $(48,48 \%)$ while there were 7 respondents reported to have more than 10 years of working experience (7\%). As for the category of age, majority of the respondents were ranged between the age of 18-25 $(54,54 \%)$ and the lowest number was represented by 3 respondents aged $46-55$ (3\%). In terms of position, most of the respondents were holding the position of staff $(70,70 \%)$ whereas there were only 7 managers among them. As for academic qualification, majority of the respondents were degree holders $(51,51 \%)$ while 11 respondents were possessing masters (11\%).

\section{Factor Analysis}

For factor analysis, the researcher used Principal Component Analysis to analyse the validity of the data. Kaiser-Meyer-Olkin for Measuring of Sampling Adequacy (KMO/MSA) and Bartlett Test of Sphericity were used to evaluate the strength among the variables. Based on Table 1 below, it shows that the result of KMO/MSA is 0.794 with Bartlett Test of Sphericity at 492.804 , sig .000 ( $p<.001)$. It is supported by Hutcheson and Sofroniou (1999) that if a value of KMO/MSA is ranging from 0.7 to 0.8 , it is considered as a good value for factor analysis. Principal Component Analysis (PCA) shows that safe working environment was eliminated due to cross loading. The rest of the components were loaded with strong loadings and categorized as compensation and benefit ( 4 items), performance management ( 3 items), follows by training and development ( 2 items) and employment security ( 2 items). Compensation and benefits contribute $36.214 \%$ of the common variance with eigenvalue of 4.346, performance management contribute $17.789 \%$ of the common variance with eigenvalue of 2.135, whereas training and development contribute $9.652 \%$ of the common variance with eigenvalue of 1.158 and employment security contribute $8.657 \%$ of common variance with eigenvalue of 1.039 . The total cumulative percentage of common variance is $72.312 \%$ and the range of factor loadings is from 0.723 to 0.914 . 
INTERNATIONAL JOURNAL OF ACADEMIC RESEARCH IN BUSINESS AND SOCIAL SCIENCES

Vol. 9, No. 3, March, 2019, E-ISSN: 222 2-6990 @ 2019 HRMARS

Table 1: Factor Analysis for HRM Practices

\begin{tabular}{|c|c|c|c|c|c|}
\hline \multirow[t]{2}{*}{ Item } & \multirow[t]{2}{*}{ Description } & \multicolumn{4}{|c|}{ Factor Loading } \\
\hline & & 1 & 2 & 3 & 4 \\
\hline TD3 & $\begin{array}{l}\text { I have the chance to make use my } \\
\text { ability }\end{array}$ & & & 0.727 & \\
\hline TD5 & $\begin{array}{l}\text { My job offer me opportunities to } \\
\text { learn new things }\end{array}$ & & & 0.773 & \\
\hline CB2 & I am satisfied with my current salary & 0.914 & & & \\
\hline CB3 & $\begin{array}{l}\text { I am satisfied with my most recent } \\
\text { increment }\end{array}$ & 0.835 & & & \\
\hline CB4 & $\begin{array}{l}\text { I am satisfied with the raises i have } \\
\text { received in the past }\end{array}$ & 0.723 & & & \\
\hline CB5 & $\begin{array}{l}\text { I am satisfied with my benefits and } \\
\text { packages }\end{array}$ & 0.862 & & & \\
\hline PM1 & $\begin{array}{l}\text { I know how my manager rates my } \\
\text { performance on work task }\end{array}$ & & 0.749 & & \\
\hline PM3 & $\begin{array}{l}\text { My performance review process is } \\
\text { standardized and documented }\end{array}$ & & 0.819 & & \\
\hline PM5 & $\begin{array}{l}\text { My promotions and pay increases } \\
\text { are based on achieving documented } \\
\text { performance objectives }\end{array}$ & & 0.787 & & \\
\hline ES2 & $\begin{array}{l}\text { If my company faces economic } \\
\text { problems, i would be the last to get } \\
\text { cut }\end{array}$ & & & & 0.845 \\
\hline ES4 & $\begin{array}{l}\text { It is very difficult to dismiss me as an } \\
\text { employee }\end{array}$ & & & & 0.841 \\
\hline Eigenv & alue & 4.346 & 2.135 & 1.158 & 1.039 \\
\hline Percer & tage of Common Variance (\%) & 36.214 & 17.789 & 9.652 & 8.657 \\
\hline Cumu & tive Percentage (\%) & 36.214 & 54.003 & 63.655 & 72.312 \\
\hline
\end{tabular}

As for the dependent variable (job performance), the Bartlett's test of Sphericity score is 144.854 , sig $.000(\mathrm{p}<.001)$ as shown in Table 2 , whereas the value of KMO/MSA is 0.788 . Both readings were considered good for factor analysis (Huctheson and Sofroniou, 1999). Based on Table 2, 2 items were eliminated due to cross loadings and left with 6 items with percentage of common variance at $47.345 \%$ and an eigenvalue of 2.841 . 
INTERNATIONAL JOURNAL OF ACADEMIC RESEARCH IN BUSINESS AND SOCIAL SCIENCES Vol. 9, No. 3, March, 2019, E-ISSN: 222 2-6990 @ 2019 HRMARS

Table 2: Factor Analysis for Job Performance

\begin{tabular}{llc}
\hline \multicolumn{1}{c}{ Item } & \multicolumn{1}{c}{ Description } & Factor Loading \\
\hline JP2 & $\begin{array}{l}\text { I do not mind taking on new or challenging } \\
\text { assignment }\end{array}$ & 0.714 \\
\hline JP3 & $\begin{array}{l}\text { I try hard to self-study to increase the quality of work } \\
\text { outputs }\end{array}$ & 0.634 \\
\hline JP4 & $\begin{array}{l}\text { I comply with company rules and procedures even } \\
\text { when nobody watches and no evidence can be traced }\end{array}$ & 0.692 \\
\hline JP6 & take the initiative to solve work problem & 0.729 \\
\hline JP7 & I tackle a difficult work assignment enthusiastically & 0.773 \\
\hline JP8 & I actively attends company meetings & 0.566 \\
\hline & Eigenvalue & 2.841 \\
\hline & Percentage of Common Variance (\%) & 47.345 \\
\hline & Cumulative Percentage (\%) & 47.345 \\
\hline
\end{tabular}

Note. $K M O=0.788$, Bartlett's test of Sphericity: Approx. Chi-Square $=144.854, p<.001$.

\section{Reliability Test}

To analyze the reliability for each variable, Cronbach's Alpha coefficient was used to describe how reliable the items are. Refer to Table 3 below, the reliability coefficient (Cronbach's Alpha) for the independent variables namely training and development, compensation and benefits, performance management, employment security was rated at $0.682,0.881,0.772$ and 0.767 respectively. Cronbach's Alpha for the dependent variable, job performance was 0.771. According to Tavakol and Dennick (2011), the acceptable value of Cronbach's Alpha shall be ranging from 0.70 to 0.95. Therefore, all the variables are deemed reliable with training and development's $(\alpha=0.682)$ reliability coefficient near to 0.70 .

Table 3: Reliability Test for the Study Variables

\begin{tabular}{cccccc}
\hline Variable & $\begin{array}{c}\text { Job } \\
\text { Performance }\end{array}$ & $\begin{array}{c}\text { Training and } \\
\text { Development }\end{array}$ & $\begin{array}{c}\text { Compensation } \\
\text { and Benefits }\end{array}$ & $\begin{array}{c}\text { Performance } \\
\text { Management }\end{array}$ & $\begin{array}{c}\text { Employment } \\
\text { Security }\end{array}$ \\
\hline $\begin{array}{c}\text { Cronbach } \\
\text { Alpha }\end{array}$ & 0.771 & 0.682 & 0.881 & 0.772 & 0.767 \\
\hline
\end{tabular}

\section{Correlation Analysis}

Pearson correlation analysis was employed to examine the correlation between job performance and the independent variables namely training and development, compensation and benefits, performance management and employment security respectively. Refer to Table 4, employment security has the strongest correlation with job performance $(r=0.598, p<0.01)$ among the independent variables. Training and development, compensation and benefit and performance management reported a significant correlation towards job performance with $r=0.558, p<0.01, r=$ $0.352, p<0.01$ and $r=0.457, p<0.01$ respectively. Based on the data analysis above, it was revealed that all independent variables were positively correlated with job performance. 
INTERNATIONAL JOURNAL OF ACADEMIC RESEARCH IN BUSINESS AND SOCIAL SCIENCES Vol. 9, No. 3, March, 2019, E-ISSN: 222 2-6990 @ 2019 HRMARS

Table 4: Correlation between Human Resource Management Practices and Job Performance

\begin{tabular}{|c|c|c|c|c|c|}
\hline & $\begin{array}{c}\text { Training } \\
\text { and } \\
\text { Developmen } \\
\mathrm{t}\end{array}$ & $\begin{array}{c}\text { Compensatio } \\
\mathrm{n} \text { and } \\
\text { Benefit }\end{array}$ & $\begin{array}{l}\text { Performance } \\
\text { Management }\end{array}$ & $\begin{array}{c}\text { Employment } \\
\text { Security }\end{array}$ & $\begin{array}{c}\text { Job } \\
\text { performance }\end{array}$ \\
\hline $\begin{array}{l}\text { Training and } \\
\text { Development }\end{array}$ & 1 & & & & \\
\hline $\begin{array}{c}\text { Compensation } \\
\text { and Benefit }\end{array}$ & $.219 *$ & 1 & & & \\
\hline $\begin{array}{l}\text { Performance } \\
\text { Management }\end{array}$ & $.448 * *$ & $.303^{* *}$ & 1 & & \\
\hline $\begin{array}{c}\text { Employment } \\
\text { Security }\end{array}$ & $.360 * *$ & $.369 * *$ & $.364^{* *}$ & 1 & \\
\hline $\begin{array}{c}\text { Job } \\
\text { Performance }\end{array}$ & $.558 * *$ & $.352^{* *}$ & $.457^{* *}$ & $.598 * *$ & 1 \\
\hline
\end{tabular}

\section{Multiple Regression Analysis}

Table 5 shows the results of multiple regression analysis among the independent variables and job performance. It was found that the model is significant with $\mathrm{F}$ value of 25.454 and able to explain 51.7 percent $\left(R^{2}=0.517\right)$ of the variance of job performance. Further examining the results revealed that training and development has a positive significant relationship with job performance $(\beta=0.336$, $p<0.001)$. It indicates that the more employees attend training, the higher their job performance. Therefore, $\mathrm{H} 1$ was accepted. Similarly, a positive significant relationship was discovered between employment security and job performance $(\beta=0.394, p<0.001)$. It explains that when employees feel secured with the current employment, they tend to produce better job performance. Hence, $\mathrm{H} 4$ was accepted (see Table 5). However, it was found that there is no relationship between compensation and benefits and job performance $(\beta=0.091, p>0.05)$. There is also no relationship between performance management and job performance $(\beta=0.135, p>0.05)$. Therefore, $\mathrm{H} 2$ and $\mathrm{H} 3$ were rejected (see Table 5). 
INTERNATIONAL JOURNAL OF ACADEMIC RESEARCH IN BUSINESS AND SOCIAL SCIENCES Vol. 9, No. 3, March, 2019, E-ISSN: 222 2-6990 @ 2019 HRMARS

Table 5: Multiple Regression Analysis among Independent Variables and Job Performance

\begin{tabular}{|c|c|c|c|c|c|c|}
\hline \multirow{2}{*}{$\begin{array}{c}\text { Independent } \\
\text { Variable }\end{array}$} & \multicolumn{4}{|c|}{ Job Performance } & \multirow[t]{2}{*}{ Hypothesis } & \multirow[t]{2}{*}{ Result } \\
\hline & $\operatorname{Beta}(\beta)$ & Sig. & Tolerance & VIF & & \\
\hline $\begin{array}{l}\text { Training and } \\
\text { Development }\end{array}$ & $0.336 * * *$ & 0.000 & 0.754 & 1.326 & $\mathrm{H} 1$ & Accepted \\
\hline $\begin{array}{l}\text { Compensation } \\
\text { and Benefit }\end{array}$ & 0.091 & 0.246 & 0.830 & 1.205 & $\mathrm{H} 2$ & Rejected \\
\hline $\begin{array}{l}\text { Performance } \\
\text { Management }\end{array}$ & 0.135 & 0.108 & 0.730 & 1.370 & $\mathrm{H} 3$ & Rejected \\
\hline $\begin{array}{l}\text { Employment } \\
\text { Security }\end{array}$ & $0.394 * * *$ & 0.000 & 0.756 & 1.323 & $\mathrm{H} 4$ & Accepted \\
\hline F value & \multicolumn{6}{|c|}{25.454} \\
\hline R square & \multicolumn{6}{|c|}{0.517} \\
\hline
\end{tabular}

$* * *$ Significant at the 0.001 level, ** Significant at the 0.01 level, * Significant at the 0.05 level

\section{Discussion}

Based on the findings of this study, it was discovered that training and development has a significant positive relationship with job performance $(\beta=0.336, p<0.001)$. It indicates that employees perceived to think that training and development will affect their job performance. This is true in the sense that training and development enhance skills and capabilities of the employees in order to achieve organization goals. When employees receive training, they will gain knowledge to apply into their works, thus their works will become much easier and consequently increase their job performance. Atteya (2012) stated that to help employees obtaining broader knowledge, skills, and abilities to work excellently, they need training and development activities. Likewise, Huselid (1995) concurred that by providing formal and informal training such as basic skills and management skill development, it is likely to further influence the employees' job performance. In addition, Tabiu and Nura (2013) revealed that most of human resource management practices influence job performance. Ong \& Koh, (2018) also emphasized in their study that organization should use training programs for its employees to achieve stronger competitive advantage. Furthermore, Arthur, Bennett, Eden and Bell (2003) concluded that training and development programs are related to job performance in the organization. Similarly, the findings also showed that employment security is significantly and positively associated with job performance $(\beta=0.394, p<0.001)$. This finding is consistent with the study of Lucky, Minai and Rahman (2013) where they revealed that employment security is related to job performance. Therefore, it is believed that employees in the courier service industry are willing to perform well as long as the company provides them with employment security. However, Kraja (2015) found that employment security does not have significant relationship with job performance. The author suggested that there is no individual can keep certain position in an organization for long term employment security. On the other hand, it was found in the findings that compensation and benefits were not significantly related to job performance $(\beta=0.091, p>0.05)$. This finding is in contrast with the study of Nabi, Syduzzaman and Munir (2016). The plausible reason to explain about this finding is that employees in the courier service industry may think that compensation and 
benefits are solely based on position and yesrs of working experience and did not link to current job performance. Likewise, performance management was found not related to job performance in this study $(\beta=0.135, p>0.05)$. This finding is not in line with the study of Atteya (2012) where it stated that performance management provides positive contribution towards job performance. The explanation of this finding is that from the employees' perspective, performance management may not really enhance job performance because it was conducted only once in a year and the responsibility for performance evaluation is generally placed on the supervisors or line managers and not the individual employee. Therefore, potential bias or rater's error may occur during performance evaluation.

\section{Conclusion}

This research has been successfully conducted and able to provide greater understanding towards the relationship between human resource management practices and job performance. This research indicates that employment security and training and development are among the best practices that employees should receive from the organization in the courier service industry. Hence, Management should show concern and provide sufficient training for employees to gain broader goals. Nevertheless, it is important for the organizations to understand that in order to increase job performance, employment security should be emphasized as it makes employees believe that they could work as long as they are being responsible for their job while the organization offers opportunities to the employees for their career development.

\section{Acknowledgements}

The authors would like to thank the Malaysian Ministry of Higher Education and Universiti Teknologi Malaysia (GUP-Vot: 14J81) for providing financial support to publish this paper.

\section{References}

Aboul-Ela, G. M. (2017). Reflections on Workplace Compassion and Job Performance. Journal of Human Values 23(3), 234-243.

Aguinis, D. H. (2013). Performance Management. Edinburgh: Edinburgh Business School.

Algorta, M., \& Zeballos, F. (2011). Human resource and knowledge management: Best practices identification. Measuring Business Excellence,15( 4), 71-80.

Amin, M., Ismail, W. K., Rasid, S. Z., \& Selemani, R. D. (2014). The impact of human resource management practices on performance: Evidence from a Public University. The TQM Journal, 125.

Armstrong M, Baron A (2004), Get into Line. People Management, 10(20) CIPD

Arthur, W., Bennett, W., Eden, P. S., \& Bell, S. T. (2003). Effectiveness of Training in Organizations: A Meta-Analysis of Design and Evaluation Features. Journal of Applied Psychology, 88(2), 234245.

Atteya, N. M. (2012). Testing the Impact of the Human Resource Management Practices on Job Performance: An Empirical Study in the Egyptian Joint Venture Petroleum Companies. International Journal of Business and Social Science, 3(9), 105-119. 
Bakker, A. B., Tims, M., \& Derks, D. (2012). Proactive personality and job performance: The role of job crafting and work engagement. Human Relations 65(10) , 1359-1378.

Bhatti, M. A., Sundram, V. P., \& Hee, H. C. (2012). Expatriate Job Performance and Adjustment: Role of Individual and Organizational Factors . Journal of Business \& Management, 1(1) , 29-39.

Borman, W.C. \& Motowidlo, S.J. (1993), Expanding the criterion domain to include elements of contextual performance, in Schmitt, N. and Borman, W.C. (Eds), Personnel Selection in Organizations, Jossey-Bass, San Francisco, CA

Caillier, J. G. (2010). Factors affecting job performance in public agencies. Public Performance \& Management Review, 34(2), 139-165.

Carlopio, J. R., \& Gardner, D. (1992 ). direct and interactive effects of the physical work environment on attitudes. Environment and Behavior, 24(5) , 579-601.

Chang, E. (2005). Employee's overall perception of HRM effectiveness. Human Relations, 58(4), 523544

Clarke, M., \& Patrickson, M. (2008). The new covenant of employability. Employee Relations 30(2), 121-141.

Coetzer, A., Redmond, J., \& Sharafizad, J. (2012). Decision making regarding access to training and development in medium-sized enterprises: An exploratory study using the Critical Incident Technique. European Journal of Training and Development, 428.

Datta, D. K., Guthrie, J. P., \& Wright, P. M. (2005). Human resource management and labor productivity: Does industry matter? Academy of Management Journal, 48(1), 135-145.

Delaney, J. T., \& Huselid, M. A. (1996). The Impact of Human Resource Management Practices on Perceptions of Organizational Performance. The Academy of Management Journal, 39(4), 949-969.

Edgar, F., \& Geare, A. (2005). HRM practise and employee attitudes: Difference measures and different results. Personnel review, 34(5), 534-549.

Farh, J. L., Earley, P. C., \& Lin, S. C. (1997). Impetus for Action: A Cultural Analysis of Justice and Organizational Citizenship Behavior in Chinese Society. Administrative Science Quarterly, 42(3), 421-444.

Fletcher, C. (2001). Performance appraisal and management: The developing research agenda. Journal of Occupational and Organizational Psychology 74, 473-487.

Friedman, R. A., Tidd, S. T., Currall, S. C., \& Tsai, J. C. (2000). What goes around comes around: the impact of personal conflict style on work conflict and stress. The International Journal of Conflict Management, 11(1), 32-55.

Hartog, D. N., Boon, C., Verburg, R. M., \& Croon, M. A. (2013). HRM, Communication, Satisfaction, and Perceived Performance: A Cross-Level Test. Journal of Management, 39(6), 1637-1665.

Giri, V. N., \& Kumar, B. P. (June 2010). Assessing the Impact of Organizational Communication on Job Satisfaction and Job Performance. National Academy of Psychology (NAOP) India Psychological Studies, 55(2):137-143.

Guthrie, J. P. (2001). High-Involvement Work Practices, Turnover, and Productivity: Evidence from New Zealand. The Academy of Management Journal, 44(1) , 180-190. 
Hameed, A., Ramzan, M., Zubair, H. M., Ali, G., \& Arslan, M. (2014). Impact of Compensation on Employee Performance (Empirical Evidence from Banking Sector of Pakistan). International Journal of Business and Social Science, 5(2), 303-309.

Hartog, D. N., Boon, C., Verburg, R. M., \& Croon, M. A. (2013). HRM, Communication, Satisfaction, and Perceived Performance: A Cross-Level Test. Journal of Management, 39(6), 1637-1665.

Heneman, H. G. III., \& Schwab, D. P. (1985). Pay satisfaction: Its multidimensional nature and measurement. International Journal of Psychology, 20(2), 129-141.

Heraty, N., \& Morley, M. (1998). In search of good fit: policy and practice in recruitment and selection in Ireland. Journal of Management Development, 17(9), 662-685.

Huselid, M. A. (1995). The impact of human resource management practices on turnover, productivity, and corporate financial performance. Academy of Management Journal, 38(3), 635-872.

Hutcheson, G. and Sofroniou, N. (1999) The Multivariate Social Scientist: Introductory Statistics Using Generalized Linear Models. Sage Publication, Thousand Oaks, CA.

Izvercian, M., Radu, A., Ivascu, L., \& Ardelean, B.-O. (2014). The Impact of Human Resources and Total Quality Management on the Enterprise. Procedia - Social and Behavioral Sciences, 124 , 27 33.

J.William, L., \& Anderson, S. E. (1991). Job satisfaction and organizational commitment as Predictor of Organizational Citizenship and In-role Behaviors. Journal of Management, 17(3), 601-617.

Johari, J., \& Yahya, K. K. (2016). Job characteristics, work involvement, and job performance of public servants. European Journal of Training and Development, 558.

Jyothi, P., \& Venkatesh, D. (2012). Human Resource Management (2nd ed). New Delhi: Oxford University Press.

Kahn, w. a. (1990). Psychological conditions of personal engagement and disengagement at work. Academy of Management Journal, 33(4), 692-724.

Karthikeyan, M., \& Elango, D. M. (2014). Minimization of Transportation Cost in Courier Service Industry. International Journal of Innovative Research in Science, Engineering and Technology, 3(3), 1116-1122.

Knudsen, H., Busck, O., \& Lind, J. (2011). Work environment quality: The role of workplace participation and democracy. Work, Employment and Society 25(3), 379-396.

Kraja, G. (2015). Job Security and Performance: Case Study of the Albanian Public Administration. Academic Journal of Interdisciplinary Studies, 4(2), 19-26.

Krejcie, R. V., \& Morgan, D. W. (1970). Determining sample size for research activities. Educational and Physiological Measurement 30(3), 607-610.

Locke, E. A., Mento, A. J., \& Katcher, B. L. (1978). The interaction of ability and motivation in performance: An exploration of the meaning of moderators. Personnel Psychology, 31(2), 269-280

Lucky, E. O.-I., Minai, M. S., \& Rahman, H. A. (2013). impact of job security on the organizational performance in a multiethnic environment. Research Journal of Business Management 7(1), 64-70. 
INTERNATIONAL JOURNAL OF ACADEMIC RESEARCH IN BUSINESS AND SOCIAL SCIENCES

Vol. 9, No. 3, March, 2019, E-ISSN: 222 2-6990 @ 2019 HRMARS

Macduffie, J. P. (1995). Human Resource Bundles and Manufacturing Performance: Organizational Logic and Flexible Production Systems in the World Auto Industry. Industrial and Labor Relations Review, 48(2) , 197-221.

Mondy, R. W. (2012). Human Resource Management (12th ed). England: Pearson Education Limited. Nabi, M. N., Syduzzaman, M., \& Munir, M. S. (2016). The Impact of Human Resource Management Practices on Job Performances: A Case Study of Dhaka Bank Pvt. Ltd.,Bangladesh. Human Resource Management Research, 6(2), 45-54.

Nadarajah, S., Kadiresan, V., Kumar, R., Nissa, N., \& Yusoff, D. Y. (2012). The Relationship of HR Practices and Job Performance of Academicians towards Career Development in Malaysian Private Higher Institutions . International Conference on Asia Pacific Business Innovation and Technology Management, 102-118.

Ong, C. H., \& Koh, R. J. (2018). The Influence of Human Resources Management Practices on Employee Performance in the Manufacturing Sector in Malaysia. International Journal of Human Resources Studies, 8(2), 129-147.

Pfeffer, J., \& Veiga, J. F. (1999). Putting People First for Organizational Success. The Academy of Management Executive, 13(2), 37-48.

Rogg, K. L., Schmidt, D. B., Shull, C., \& Schmitt, N. (2001). Human resources practices, Organizational climate and customer satisfaction. Journal of Management, 27(4), 431-449.

Rotundo, M., \& Sackett, P. R. (2002). The Relative Importance of Task, Citizenship, and Counterproductive Performance to Global Ratings of Job Performance:A Policy-Capturing Approach. Journal of Applied Psychology, 87(1), 66-80.

Sang, J., Korir, M., \& Wishitemi, B. (2016). Selected Human Resources Factors as Determinants of Performance Management Framework Implementation in Kenya. International Journal of Business and Management, 11(9), 192-206.

Schuler, R. S., \& Jackson, S. E. (1987). Linking Competitive Strategies with Human Resource Management Practices. The Academy of Management Executive, 1(3), 207-219.

Tabiu, A., \& Nura, A. A. (2013). Assessing the effects of human resource management (HRM) practices on employee job performance: a study of Usmanu Danfodiyo University Sokoto. Journal of Business Studies Quarterly, 5(2), 248-259.

Tavakol, M., \& Dennick, R. (2011). Making sense of Cronbach's alpha. International Journal of Medical Education, 2, 53-55.

Vlachos, I. P. (2009). The effects of human resource practices on firm growth. International Journal of Business Science and Applied Management, 4(2), 18-34.

Vratskikh, I., Masadeh, R., Al-Lozi, M., \& Maqableh, M. (2016). The Impact of Emotional Intelligence on Job Performance via the Mediating Role of Job Satisfaction. International Journal of Business and Management, 11(2), 72.

Wright, P. M., Gardner, T. M., Moynihan, L. M., \& Allen, M. R. (2005). The Relationship Between HR Practices and Firm Performance: Examining Causal Order. Personnel Psychology Journal 58(2), 409-446.

Yang, C. L., \& Hwang, M. (2014). Personality traits and simultaneous reciprocal influences between job performance and. Chinese Management Studies, 9. 
INTERNATIONAL JOURNAL OF ACADEMIC RESEARCH IN BUSINESS AND SOCIAL SCIENCES Vol. 9, No. 3, March, 2019, E-ISSN: 222 2-6990 @ 2019 HRMARS

\section{Corresponding Author}

Ong Choon Hee

Email: ongchoonhee@gmail.com 